Western University

Scholarship@Western

FIMS Publications

Information \& Media Studies (FIMS) Faculty

2003

Neo-Imperialism and the Crisis of Time

Edward Comor

University of Western Ontario, ecomor@uwo.ca

Follow this and additional works at: https://ir.lib.uwo.ca/fimspub

Part of the Library and Information Science Commons

Citation of this paper:

Comor, Edward. "Neo-Imperialism and the Crisis of Time." Topia: Canadian Journal of Cultural Studies 10 (2003), 1-21. 


\title{
Neo-Imperialism and the Crisis of Time'
}

\begin{abstract}
This article applies the Innisian concept of media bias to contemporary U.S. foreign policy developments. The author argues that the common sense informing an emerging neo-imperialism has been profoundly influenced by Washington's general neglect of time. Among others, consumption is assessed as a medium shaping such biases as well as contradictory policies related to the globalization project.
\end{abstract}

All right, let me see if I understand the logic of this correctly?

We are going to ignore the United Nations in order to make clear to Saddam Hussein that the United Nations cannot be ignored. We are going to wage war to avert the United Nations' ability to prevent war.The paramount principle is that the UN must be taken seriously and, if we have to subvert its word in order to guarantee that it is, then, by gum, we will... Further, if the only way to bring democracy to Iraq is to vitiate the democracy of the Security Council, then we are bonor bound to do that too because democracy as we define it is too important to be stopped by democracy the way they define it... We are sending our gathered might to the Persian Gulf to make the point that might does not make right-as Saddam Hussein seems to think it does-and we are twisting the arms of the opposition until it agrees to let us oust a regime that twists the arms of the opposition. We cannot leave in power a dictator that ignores his own people and if our people, and people throughout the world, fail to understand that, then we must ignore them. 
Look, please don't misunderstand. I think it's a good thing that members of the Bush Administration have been reading Lewis Carroll. I only wish that someone bad pointed out that Alice in Wonderland and Through the Looking Glass are meditations on paradox, and puzzle, and illogic, and on the strangeness of things, not templates for foreign policy.

Peter Freundlich, American journalist commenting on National Public Radio (March 13, 2003).

In his sardonic reflection on the upside-down logic used to justify America's invasion of Iraq, Peter Freundlich underlines the web of contradictions pervading U.S. foreign policy-contradictions that have not gone unnoticed by most around the world and many within America's borders. Like many others, through omission, Freundlich does not begin the important task of deciphering the logic informing the illogic, and no attempt is made to situate the flexing of Washington's unilateralist muscle in the kind of context needed to make sense of the seemingly senseless.

The power of the American state in international affairs has been the subject of countless strategic studies, critical assessments and resistance projects. In the midst of what may well be an endless "war on terrorism," debates concerning the policies informing the use of America's military resources are now congealing around the problematic process of occupying and "democratizing" Iraq. In what follows, I take a step beyond and back from such analyses by relating the rationale behind contemporary policies to what Harold Innis, many years ago, referred to as a civilizational crisis involving time. While much attention has been paid to the spatial conquest, occupation and reorganization of the world, it is my view that more profound questions lie before us concerning how time is being organized and conceptualized in Washington and the implications of these temporal norms on what is deemed to be rational policy-making. ${ }^{2}$

Herein I argue that the Alice in Wonderland policies promoted by the White House and U.S. Defense Department can be viewed in terms of something more disconcerting than the preferences of an extraordinarily hawkish administration. These policy choices-reflected in what has become a characteristically unilateralist and militaristic foreign policy - are rooted in the soils of two mutually supportive historical developments: America's military, political and economic dominance in relation to other countries and what can be described as an increasingly arrogant and, from a Gramscian perspective, often reactionary common sense. But still more deeply entrenched and disturbing are the cultural-temporal orientations shaping the thoughts and actions of the U.S. foreign policy intelligentsia. Contemporary American policies are responses to and are themselves perpetuating an ongoing neglect of humanity's long-term needs. Such tendencies have been ingrained in structures, practices and thinking processes. With eyes cast on contemporary U.S. foreign policy developments, I set out to decipher the logic informing the illogic.

The United States has become extraordinarily important in the complex drive to expand and speed up global capitalism. Through what can be termed the globalization project-a project involving free trade agreements, intellectual property arrangements, communications and information technology infrastructures, and diktats 
conveyed to governments through international organizations (and, of course, the direct interventions of American state and corporate personnel)—this expansion and speed-up, in the 1990s, was pursued through the construction of a largely consensual international order. This project has involved powerful agents structuring media (broadly defined, as in Innis's use of the term) in ways designed to shape what is acceptable, rational and imaginable. More generally, the globalization project involves efforts to widen and deepen a general tendency of capitalist political economies: the systemic obsession with spatial expansion, organization and control through evershortening timeframes involving a neglect of social conceptualizations of time.

Through an elaboration of this general (but not in itself determining) process the logic behind the illogic of contemporary U.S. foreign policy can be identified and, potentially, redressed. Through this together with an application of Innisian concepts by an overtly subjective Canadian political economist formerly based in Washington, DC (where I taught in a Department of International Relations from 1995 to 2003), I relate current policy developments informing the invasion of Iraq and the war on terrorism to a wider, more entrenched crisis concerning time.

\section{The Neo-Imperialist Turn}

While the expansionist tendencies of the United States have been well documented by historians (LaFeber 1963; Williams 1972), only in recent years has the notion of a grand neo-imperialist project been the subject of open debate in Washington. Following the end of the Cold War, in light of the many problems facing the globalization project, and in response to the terrorist attacks of September 11,2001, the concept of empire has become an increasingly in-vogue part of think tank and academic hallway discourse. Echoing the self-assumed benevolence of the British in the nineteenth century, and Rome after Augustus, proponents of a neo-imperialist American-centred world order emphasize the virtues of liberal democracy and the material benefits of the market system. The latter, framed in terms of what George Soros calls "market fundamentalism" (involving the lowering of taxes, pro-growth regulatory reforms and the opening-up of markets for investment and trade), the world envisioned by the Washington Consensus ${ }^{3}$ is, in its application, a system of political-economic dominance with the American state as the core nodal point of power.

The globalization project and its ideological justification preceded contemporary talk about a neo-imperialist foreign policy. The call for empire has surfaced as a "reasonable" policy option in conjunction with upheavals related to the project's many failures. Writing a year before the September 11 attacks, Richard Haas (special assistant and member of the National Security Council under the first President Bush, and Director of Policy Planning in the State Department under the second Bush) argued in a paper titled "Imperial America" that the United States should embrace its role as an imperial power. America, Haas argued, not only has before it the strategic opportunity to "extend its control" over world affairs, it has a moral responsibility to "grace" the globe with its model of "free markets, human rights and democracy, enforced by the most awesome military power the world has ever known" (Haas, 2000). Picking up on this point, Stephen Peter Rosen of the Olin Institute for Strategic Studies opined that "a political unit that has 
overwhelming superiority in military power, and uses that power to influence the internal behavior of other states, is called an empire. Because the United States does not seek to control territory or govern the overseas citizens of the empire, we are an indirect empire, to be sure, but an empire nonetheless. If this is correct, our goal is not combating a rival, but maintaining our imperial position, and maintaining imperial order" (Rosen, 2002: 29).

Underlining that an empire is not necessarily a bad thing, Wall Street Journal editor Max Boot reassures his readers that "Many have suggested that the September 11 attack on America was payback for U.S. imperialism ... [and that the] United States must become a kinder, gentler nation ... [,] must become ... a republic, not an empire." Wrong, says Boot, explaining that:

this analysis is exactly backward: The September 11 attack was a result of insufficient American involvement and ambition; the solution is to be more expansive in our goals and more assertive in their implementation.... America now faces the prospect of military action in many of the same lands where generations of British colonial soldiers went on campaigns.... Afghanistan and other troubled foreign lands cry out for the sort of enlightened foreign administration once provided by self-confident Englishmen.... Killing bin Laden is important and necessary; but it is not enough. New bin Ladens could rise up to take his place. We must not only wipe out the vipers but also destroy their nest and do our best to prevent new nests from being built there again. (Boot, 2001)

What is extraordinary about these and many other proclamations regarding America's "responsibility" to take on the imperialist mantle is that they are being made publicly. ${ }^{4}$ Until very recently, sentences linking the United States with empire were not to be uttered in the polite company of Georgetown and Capitol Hill cocktail parties. Regardless of well-documented indices suggesting a long-established imperialist orientation, to associate America with the Romans or the British was out of bounds. Not long after the Second World War, however, the United States had over a thousand military bases around the world-an overseas presence far exceeding that of any power in history. By the 1990s, the number of these bases had been roughly halved (understandable in light of the end of Cold War hostilities), but this trend was counterbalanced by the rising number of U.S. military personnel deployed overseas in temporary operations. In 1999, such American forces were present in about one hundred countries (Arkin, 2002). This transition from permanent bases to flexible deployments was not simply a cost-saving measure, but a conscious strategic shiftaway from the containment of communism and toward mobility, speed, and overwhelming technological superiority. Today, American military expenditures are greater than those of the world's next seven largest powers combined (Rosen, 2002: 29).

While this overwhelming might has become the core doctrine of U.S. defense policy (and, with it, the evaporation of what the first President Bush called the post-Cold War peace dividend), a question rarely addressed is: what and who is this defense policy defending? Since the early 1990s, a number of the current Bush administration's most influential officials actively promoted the notion that America's unparalleled military 
capabilities and political-economic power constituted a window of opportunity-an opportunity to re-cast global structures in accordance with U.S. strategic interests. A document concretizing this perspective was released by the White House in 2002 . Called the National Security Strategy of the United States of America, three principles for American foreign policy in the twenty-first century are made explicit: first, the existing global dominance of the U.S. military must be perpetuated in order to prevent any prospective rival from aspiring to challenge its position; second, America has the right to take exception to international norms and engage in preemptive military strikes; and third, U.S. citizens should be immune from prospective prosecutions by the newly established International Criminal Court (2002).

In the security strategy, democracy and development are intimately associated with free markets, lower taxes, pro-growth regulations and expanding trade regimes. Together they constitute what is called "a single sustainable model for national success" (ibid: Introduction). Elsewhere, the report argues that this position transcends economic theory:

The concept of "free trade" arose as a moral principle even before it became a pillar of economics. If you can make something that others value, you should be able to sell it to them. If others make something that you value, you should be able to buy it. This is real freedom, the freedom for a person-or a nation-to make a living. (Ibid: Chapter 6)

To begin the task of historicizing this policy, we might start with some clarification on the role of the nation-state (and, indeed, the American state) at this juncture in history. Leo Panitch and Sam Ginden (2002) demonstrate that transnational corporations and investors have become more than just integrated into national decisionmaking processes. In recent years, domestic interests have become increasingly focused on external forces and opportunities. Rather than an either/or argument, in which these developments reflect the absolute decline of state power (in which a tidal wave of global forces compel nation-states to respond) or the ascendancy of transnational structures and networks that somehow determine the thought processes of those developing and implementing domestic and international policies, a more logically and empirically sustainable approach is that we are living through the fallout effects of contradictions and crises taking place within states as they try to manage their domestic political economies in a relatively volatile and dynamic period of history (Panitch and Ginden, 2002: 14). ${ }^{5}$

From this vantage point, the United States stands in a unique position. Like other countries, the American state is engaged in a complex juggling act: accommodating foreign corporations and investors within its borders while it assists domestic interests to respond to overseas pressures while also enabling some to take advantage of emerging international opportunities. But the American state also stands as the core mediator of a more ambitious task-it is the only nation-state possessing the power resources needed to unilaterally pursue the more universal globalization project. ${ }^{6}$

Before proceeding, a response to those who view the globalization project as the progenitor of global justice and prosperity is in order. ${ }^{7}$ Notwithstanding the ideals 
conveyed in market fundamentalist discourse, not only does the United States itself practice free trade selectively, American officials consistently "prevent poor countries from exploiting their few advantages on the world market" (Finnegan, 2003: 42). Through the international organizations it dominates-particularly the World Bank and the IMF - neo-classical economic development policies have been imposed on countries with little regard for the preferences of domestic populations or the mandates of elected governments. Historically such policies were not applied by the world's relatively developed economies and even today the United States rarely follows the prescriptions it imposes on others. Highly selective free trade practices, the strategic use of deficit spending, the government's subsidization of domestic corporations through the Pentagon's budget, tax policies and other means-all commonplace inside the beltway - are unacceptable options for the world's relatively vulnerable nations. While some less developed countries have experienced strong economic growth rates in recent years, none of the poster children for market fundamentalist policies have, in fact, followed Washington's market fundamentalist playbook. China, India, South Korea, Taiwan, Singapore, and others have introduced strategic tariffs, backed some sectors over others, and funneled government funds toward the promotion of public education and other infrastructural priorities providing them with the structures needed to build wealth and to weather some of the destructive effects of the globalization cyclone (Weller, et al., 2001). ${ }^{8}$ Some of the more deleterious implications of this "success" (such as environmental degradation and cultural upheaval), infamously referred to by mainstream economists as externalities, are dismissed under the "if-you-want-to-makean-omelet-you've-got-to-break-some-eggs" theory of development. Far from a moral mission to promote prosperity and freedom around the world, the globalization project, informed by market fundamentalist principles and backed up by overwhelming military capabilities, constitutes a concerted effort to re-make the world in accordance with American interests and, more abstractly, the perceived structural interests of global capitalism. ${ }^{9}$

Just as those who enjoyed the benefits of Roman citizenship under the Empire before AD 212 were outnumbered by those who did not, those benefiting from the world order being forged through the American state are in the minority. U.S. foreign policyinvolving the distribution of goodies to the compliant and punishments levied against the uncooperative-constitutes a political-economic toolbox drawn upon in the task of prying-open and re-structuring international and foreign markets in ways that serve the perceived interests of the core and the growth potentials of the capitalist system in toto. ${ }^{10}$ Such reforms do more than just funnel wealth out of the developing world into the hands of the already wealthy. They also serve to reform the global political economy in ways that entrench disparities, perpetuating a neglect of time.

\section{The Globalization Project Challenged}

The globalization project owes much of its success to the fact that it constitutes a mythological construction (Babe, 1995: 75-80; Parker, 1994) enabling people to get on with their lives through the use of a broadly sketched-out intellectual roadmap-a compass amidst the insecurities characterizing the emerging post-Fordist politicaleconomic (dis)order (Harvey, 1989). ${ }^{11}$ Once the globalization myth ascribes desirabil- 
ity or inevitability to the project, a subset of common sense assumptions such as the idealization of marketplace mechanisms to provide for people's needs, liberal-democracy as a universal ideal (and the notion that capitalism is the only realistic path to it) and, of course, the view that the days of democratic power through the nation-state are numbered, come to the fore. This framework now defines the boundaries of what is imaginable, acceptable and rational. In recent years, the tapestry representing this myth has been fraying. In the United States, this began in the wake of the anti-globalization protests in Seattle. A number of remarkable people-the former Chief Economist of the World Bank, Joseph Stiglitz, among them-subsequently raised critical questions concerning the project and its corporate rather than human priorities (Soros, 2002; Stiglitz, 2002). With empirical evidence coming to light that the poor of the world have been getting poorer (UNDP 1999; Weller, et al., 2001), it became apparent to many that the recipe for development promoted by Washington was producing a way of life quite indigestible for billions. ${ }^{12}$

Even before 9/11 a shadow had thus been cast over globalization as a reliable roadmap. Viewing these developments from downtown Washington, the challenge to globalization's status as a consensual project compelled relatively few to reassess market fundamentalism and the unilateralist course of U.S. foreign policy (although some occupying the political margins-Ralph Nader and Pat Buchanan, for example-certainly did). Instead, resistance to the project has served to reaffirm the relevancy of military power. One of the more influential organizations shaping this view and the unilateralist response to foreign opposition is the Project for the New American Century. Established in 1997 by William Kristol and others, its active members prior to the Presidential election of 2000 constituted something of a Who's Who of the current Bush administration, including Dick Cheney, Donald Rumsfeld and Paul Wolfowitz. The organization's principles are based on what it calls a Reaganite approach to the world. America's "military strength and moral clarity" inform the need to increase defense and security expenditures, directly challenge hostile regimes, and pursue "economic freedom" abroad. Additionally, the Project for the New American Century emphasizes the need of the United States to "accept responsibility for ... preserving and extending an international order friendly to our security, our prosperity and our principles" (Project for the New American Century, 1997).

Such views also were taking root in the late1990s among others not usually associated with neo-conservative America. Anticipating the need to keep dissenting states and movements in line, Zbigniew Brzezinski, President Jimmy Carter's National Security Advisor, argues in his book The Grand Chessboard: American Primacy and its Geostrategic Imperatives, that the main task at hand is "to prevent collusion and maintain dependence among the vassals, keep tributaries pliant and protected, and to keep the barbarians from coming together" (1997: 40). For Brzezinski, the barbarians are those who violently resist the globalization project. Now in the context of America's war on terrorism, they include anyone not sharing Washington's idealization of liberal democracy and the desirability of a capitalist-friendly world order. But as American diplomat John Brady Kiesling, in his 2003 resignation letter to Secretary of State Colin Powell, pointed out, oderint dum metuant (Caligula's favourite quotation from the pre-Republic poet Lucius Accius meaning "let them hate so that they fear") as a motto for handling international affairs is inherently contradictory (2003). 


\section{Knowing Time and Space}

Heuristic tools that can help us understand why the crisis facing the globalization project has generated such a reactionary foreign policy in Washington can be drawn from Innisian medium theory. Rather than viewing ways of thinking as the projections or distortions of some kind of more essential reality, medium theory understands that all human relationships and communications are mediated. As such, media (broadly defined to include technologies, organizations and institutions) are inextricable components in the process through which knowledge itself exists as reality. Instead of a potentially reductionist analysis, or a vaguely defined dialectic involving the base-superstructure metaphor, the Innisian concept of bias concentrates on how media structurally affect the process through which reality is constructed or challenged. In the context of life under capitalism, those who possess extraordinary amounts of wealth tend to, directly or indirectly, exercise extraordinary power in shaping this reality. While media constitute the social environments through which human relations take place and conceptual systems are shaped, such environments are never entirely self-contained. It is in this complex process, through the structuring of media (from educational institutions to television, from religious organizations to newspapers) and their implications in relation to conceptual systems, that Marx's thesis that "The ideas of the ruling class are in every epoch the ruling ideas" (Marx and Engels, 1970: 64) can be fleshed out.

Innis developed his concept of media bias in decidedly non-deterministic ways. The structural biases of predominant media shape conceptual systems because some ways of thinking and acting are rendered relatively more or less normal, desirable and realistic. Innis's main goal in The Bias of Communication (1982) is to use media as focal points through which macro-historical developments can be better understood in relation to the micro-level of conceptual systems. For Innis, periods of uncertainty or crisis constitute moments in which the ability of dominant interests to directly shape reality (or, in his words, monopolize knowledge) - to control how time and space are organized and conceptualized-is challenged as a result of deepening contradictions. Today, the decline in the capacity to maintain territorial control or control time through mostly consensual means is reflected in the questioning of and resistance to the common sense of market fundamentalism and Washington's militaristic responses. Vested interests, through various means including the American state, have been compelled to construct strategic media in an effort to re-assert or extend their monopolization of knowledge.

"Each civilization," Innis warned,"has its own methods of suicide" (1982: 141). Indeed, in the context of an emerging U.S. neo-imperialism (not to mention the abject hopelessness festering in some of the world's political-economic peripheries), one should anticipate that temporary solutions, including the neutralization of Saddam Hussein and other such barbarians, likely will result in still more entrenched, less resolvable crises in the near future. In the short-term, globalization's encroachment on various traditional economies and cultures involves stark disparities and conflicts among differentially biased peoples. Lewis Carroll shows in Wonderland that his characters' conceptions of time depend on and affect wildly varying realities. In the long-term, the perpetuation of space-controlling and time-annihilating media (such as the price system, trade agreements, military technologies and a range of electronic entertainments) likely will serve to sharpen already conflicting and contradictory biases. 


\section{Media and the Neglect of Time}

Historically structured media have hastened capital's systemic drive for spatial expansion in conjunction with the interrelated overriding of time. To illustrate this point I now turn to a central institution promoting such biases-consumption. Consumption affects and is affected by the political, economic and environmental circumstances in which it is practiced and by the implications of other institutional, organizational and technological media. In relatively developed economies, consumption has played a central role in the struggle to entrench or resist an existing or prospective hegemonic order. Beginning in the 1920s, advertisers and marketers responded to urbanization, industrialization and Taylorist methods of organizing production by associating commodities with the desire for cultural security, love, and community. The advertising and marketing industries emerged as core agents promoting consumption as an institution whose raison d'etre went far beyond the survival of the species. Resistance to an emerging consumer society in the name of frugality was countered through the persistence of corporate advertising and the growth of disposable income and credit. Over the course of the past eighty years consumption has become an institutional focal point through which conceptual systems have been modified to associate commodities with happiness and a meaningful life (Ewen, 1976; Leiss, et al., 1990).

In this process, traditionally conservationist and communally aware ways of living and thinking have been marginalized. Through consumption and its deepening impact on family relations, child-rearing, sexuality, recreational norms, religion and other social institutions, immediate gratification and individualist satisfactions have been promoted to the extent that short-term me-first orientations now play a significant role in the common sense of most Western cultures. From an Innisian perspective, this contemporary institution has become a core medium affecting how many Americans and others process reality. Consumption emphasizes the short-term over the long-term, the sensational over the intellectual, and the here-and-now of the individual over the organic and collective.

Through $\$ 450$ billion in worldwide advertising expenditures in 2002 alone (Coen 2002) and through the daily experiences of human beings as consumers, consumption has become a crucial medium through which ways of organizing and conceptualizing time and space are modified. This is not to say that the ideals promoted by advertisers are passively embraced. One of the reasons for the ongoing growth of advertising expenditures, as well as consumption's penetration into traditionally less-commodified institutions like childhood, spirituality, or humanity's relationship with the ecosystem, is that people often resist. From the vantage point of medium theory, consumption and other nodes of human relations have influenced not only the biases of those promoting the globalization project but also the biases of those resisting it. We must not romanticize resistance as being voluntaristically progressive. Indeed, in recent years, resistance to the globalization project has been fragmented and temporally limited. As the terrorist attacks perpetrated by both Islamic radicals and white-male "homegrown" terrorists indicate, resistance itself may be becoming more reactionary (as opposed to creative or progressive)-paradoxically echoing the self-proclaimed neoimperialists in Washington. ${ }^{13}$ 
The intensified introduction of a broad range of media, including modifications to consumption taking place through the globalization project, constitutes a significant cultural and political-economic disjuncture: a disjuncture in how those in the political, economic and cultural core and those occupying the peripheries organize and conceptualize time and space. As a means of spatial control, consumption has become a strategic medium challenging and affecting, among other things, our sense of time. A foreign policy focus on commercial access, regulatory harmony and flexibility in the production process has emphasized spatial reach to the neglect of tradition and intergenerational needs.

Contemporary consumption's emphasis on individual satisfaction and immediate gratification has exploited and deepened the human inclination for social connection and meaning. Television, whose economic mandate in the United States is to deliver eyeballs to advertisers, links people to their broader (but commercially mediated) communities while simultaneously isolating them in their homes. Personal communication technologies fulfill the desire of many to escape from the here-and-now, distancing human beings from one another while, at the same time, connecting them to others. ${ }^{14}$

Complementing this mediated isolation and perpetuating the immediacy of things is the price system. So long as the individual-through the individualizing wage labour contract-has money, she/he can buy virtually anything, anytime. Unlike the gift economy (in which one had to be an intimate member of a community to receive the goods and services needed to survive), or the barter system (in which some direct relationship with another human being was required for an exchange to take place), money, credit cards, and technologies such as the Internet no longer require human beings to know or, indeed, even care about one another. Money is now the ultimate arbiter of value. As old needs are satisfied, new needs emerge; the agents promoting consumption try to convert these needs into necessities that purportedly can be satisfied through individual success in a competitive wage labour system.

\section{The Ascendancy of the Sensual}

According to a study conducted in the year 2000, three-quarters of Americans under the age of thirty, and 54 percent over fifty, watch the news on television with a remote control in hand (Gitlin, 2001: 72). This should not be surprising in a culture whose predominant media are structurally oriented to promote immediacy, individualism and sensation to the neglect of thought and duration. American television news has changed over the decades from a stoic and stationary presentation into an increasingly image-based and sensational experience. Like advertising and marketing, news tends to promote sensual rather than thoughtful desires and responses-an orientation that helps explain Innis's observation that American imperialism involves its paradoxical attractions. Broadcasters explain that this sensual orientation and speedup is an ongoing response to the remote control, shortening attention spans and their need to pay the bills through advertising. Now that the Internet is taking viewers away from commercial television (Comor, 2000), these tendencies are intensifying. News, public affairs and the norms of political discourse have followed suit as debates are 
dominated by patriotic sound-bites, black-and-white confrontations and pomposity disguised as expertise. As Todd Gitlin observes, "American broadcasting ... gains our attention by virtue of being kinetic, episodic, personalized, and conflictual, because it systematically breaks large subjects into small chunks.... [I]t leads to simplification ... [and] hollows out public life altogether" (2001: 165). ${ }^{15}$

The use of violence and sensation to hold audiences in an ever-more commercially mediated culture has distanced many from the implications of war. In the United States, President Bush can issue "Wanted Dead Or Alive" proclamations against America's enemies and few, domestically, think twice about it. Like Charles Bronson's character in the popular 1970s film Death Wish, whose law-abiding daily life is shattered when his wife and daughter are brutally attacked,9/11 was the day in which innocent Americans were victimized. With the United Nations (or, in Bronson's case, the New York Police Department) unable or unwilling to respond in kind, Bush/Bronson believe they have no choice but to take the law into their own hands. America must act decisively to restore order. In this context, vengeance is justice. ${ }^{16}$

To take liberties with Marx, people construct their material and psychic realities but not necessarily through the conceptual systems of their own choosing. Human beings, structuring or re-structuring media in the context of perceived political-economic interests using existing conceptual systems, are not inherently critical or reflexive. Temporal and spatial biases are perpetuated as reforms and inventions tend to take on the priorities, qualities and intersubjective mandates of already predominant media.

Temporal Neglect-cum-Imperial Policy

Q:Are the American people themselves convinced by all this? Are they convinced, indeed, given the fact that the American government sold these weapons to Saddam Hussein in the first place?

A: Oh, we're not very big on bistory and right now, today, it's the Superbowl that matters to most Americans... As a people, we live very much in the present.

Hume Horan, former U.S. Ambassador in the Middle East, interviewed on BBC World News, January 26, 2003.

United States-based responses to anti-American terrorism, and more generally to those resisting the globalization project, have involved efforts to reinforce or re-structure how time and space are organized and conceptualized. Free trade agreements, for example, constitute not just the post-Fordist opening up of markets, access to labour, and the institutionalization of commerce-friendly norms, but are also efforts to recast the globe spatially and temporally. Space has been opened up by delimiting the territorial sovereignty and the buffering capabilities of other governments. Time has been challenged through the speed-up of capital turnover and more general acceleration of everyday life in the name of efficiency. In the words of U.S. Trade Representative official Emory Simon, the American state is using such international agreements to restructure "the overall environment that creates our competitiveness" (qtd. in Comor, 
1998: 150). Use of the American military to overthrow potentially oppositional regimes, such as Hussein's Iraq, are extensions of these efforts. Terrorist attacks and uncertain energy costs are disruptive to global corporate planners and to America's consumerfueled political economy. Rather than repairing the historical-material roots of terrorism and reforming an oil-dependent economic system, policies forged in response to such attacks and crafted to stabilize energy prices paradoxically may enrich the soils in which these destabilizing forces are rooted. Because they involve the structuring and re-structuring of media in accordance with pre-existing biases and conceptual systems, such solutions, over time, will exacerbate existing problems, making crises less correctable, rather than more so.

While many foreign policy hawks called for regime change in Iraq soon after the Gulf War, the explicit formulation of such a policy emerged in the mid-1990s. Richard Perle (George W. Bush's first Chairman of the Defense Policy Board), for example, co-authored a report for the Washington-based Institute for Advanced Strategic and Political Studies called A Clean Break: A New Strategy for Securing the Realm (Perle, et al., 1996). Perle makes the argument that the best way to secure American interests in the Middle East is for the United States to overthrow those governments pursuing anti-Israeli policies. Iraq was on the top of the report's hit list. Ridding Iraq (possessing the world's second largest proven oil reserves) and the Middle East of Hussein also is viewed as the first domino en route to an externally imposed reform of the Organization of Petroleum Exporting Countries (OPEC). Rather than just access to oil, the use of military power to put in place a regime friendly to U.S. interests is meant to send an explicit message to Saudi Arabia (the world's largest oil producer) and others (including the potentially problematic Chavez government in Venezuela) that oil must be priced and supplied in accordance with the needs of global capital as defined by Washington. Moreover, the threat of significantly lower oil prices, made possible through Iraq's potential withdrawal from OPEC, would, it is assumed, compel the Saudi royal family to reverse its long-standing tolerance (and purported financing) of al Qaeda and other such organizations. ${ }^{17}$

The National Security Strategy of the United States, mentioned above, was released one year after 9/11. Beyond its call to develop military capabilities and legal principles to combat terrorism, it asserts America's permanent military dominance in the world: "our forces," it assures its readers, "will be strong enough to dissuade potential adversaries from pursuing a military build up in hopes of surpassing or equaling the power of the United States" (2002: Section IX). For almost a century, the resources of the American state have been mobilized to maintain the status quo of domestic and/or transnational capitalist interests in periods of relative economic stability. In times of recession or depression, when a consensual Pax Americana is challenged, American power usually is reasserted through the use of force. ${ }^{18}$ Domestic and international media are structured or re-structured in response to such crises facilitating the search for new markets, new sources of labor, new ways to increase efficiencies and extend accumulation opportunities against an anticipated future threat. As historian William A. Williams writes, as this history has unfolded, there has been a traceable "loss of the capacity to think critically about reality" (Williams, 1972:303). ${ }^{19}$

In assessing U.S. foreign policy and its twenty-first century neo-imperialist incarnation, I have argued that ahistorical and unreflexive ways of thinking have become 
entrenched in the minds of key American decision-makers and many of its citizens. One also could argue that this policy turn reflects the dominance of positivist social science in the field of international relations. Usually referred to as neo-realism, it is the "legitimate" approach and epistemology used by strategists assessing the world from within the beltway. For neo-realists, the unit of analysis is the nation-state engaged in a contest for power in which the primary resource is military might. From an Innisian perspective, neo-realism constitutes yet another structured, power-laden medium, reflecting historical forces and processes, supported but rarely challenged by other media and through its daily use in foreign policy circles. Through this institution, U.S. foreign policy represents an ongoing calculation of "rational" nation-state interests and time is delineated by the number of moves that can be anticipated on the flat surface of a cause-and-effect Machiavellian chessboard.

The practices and thoughts of more people in more parts of the world are becoming similarly focused on immediate concerns and here-and-now needs over the long-term and collective. Opposition to the globalization project and the neo-imperialist turn in U.S. foreign policy may splinter on the rocks of shrinking attention spans and an immediate gratification mode of dissent. What Innis identified as the deadly spiral of deepening biases may hinder the capacity of the world's political, economic and cultural peripheries to counter conceptual systems oriented toward timely results. To resist within the core entails the adoption of predominant biases involving sound-bite debating points and public relations sensations-arguably a strategy that serves to perpetuate the very biases that must be countered. But to resist from outside the core leaves a movement vulnerable to being labeled as barbarians and thus targeted by American forces. The Pentagon's request for funds in the 2004 federal budget to develop a new class of nuclear weapons designed to penetrate bunkers, beyond ending the taboo against using such weapons for anything other than deterrence, will likely accelerate the efforts of "rogue states" fearing American intervention to develop their chemical, biological and nuclear arsenals. In this instance, more might applied to apparently immediate threats likely will produce more barbarians and, subsequently, more barbarism.

\section{Contradiction, Resistance and a Plea for Time}

The state of Washington's temporal mindset can be further articulated through the typology laid out in George Gurvitch's The Spectrum of Social Time (1964). In this book, Gurvitch associates a particular sense of time with various social formations-a general but useful framework in the context of this paper. Perhaps the most apparent temporal bias shaping the contemporary U.S.-centered world (dis)order is what he terms erratic time. This is a way of organizing and conceptualizing time whereby the present prevails over either the past or the future. It is a temporal bias that, predictably, involves great uncertainty and relatively apolitical collectivities. As a medium, consumption promotes such here-and-now sensibilities. Also promulgating erratic time are organizations such as the WTO (not to mention the U.S. government) that compel a growing number of people to focus on their immediate survival in the context of "normal" marketplace insecurities.

Another way in which time is being practiced and conceptualized is time in advance of itself. This involves the future's inevitably innovative qualities. Certainly, the Internet and 
the digitalization of television-with the immediacy of their endless and interactive consumerist choices-constitute the most compelling of contemporary tecnologies mediating this way of organizing and conceptualizing time. The built-in-obsolescence of commodities and their purported satisfactions also perpetuate time in advance of itself.

A third aspect of now predominant temporal biases is deceptive time. This is a rather modernist way of structuring temporal relations according to a largely mechanized and ordered sense of time. Deceptive time, says Gurvitch, is experienced through the routines of daily existence, occasionally disrupted by crisis. Again, a broad range of media are involved in its promotion, from the institution of the 40-hour work week, to organizations such as educational systems that structure activity and thought from an early age, to technologies such as mechanical clocks. All serve to schedule and discipline lives and thoughts.

In "A Plea for Time," a paper delivered to the University of New Brunswick in 1950, with U.S. foreign policy in mind, Innis warned his audience that civilizations driven to expand and control space tend to become debilitated by their subsequent neglect of time-a neglect, it should be underlined, that is reproduced through media biases affecting and affected by conceptual systems (Innis, 1982: 61-91). While living and working in Washington, I have come to the not altogether original realization that while America's immediate enemy may well be those who refer to Westerners as the infidels, the more dangerous threat lies from within. It is, among other things, America's neglect of time in favor of spatial control that, ultimately, will undermine the country's neoimperialist aspirations-an orientation succinctly represented by its troops' defense of the Iraqi oil fields and Oil Ministry but their indifference to the fate of the Iraqi National Museum, its National Library and their holdings representing 12,000 years of history.

Exercising power through military might, fueled by enormous wealth, the Bush administration is using its war on terrorism as a vehicle in which to re-organize the Middle East and curtail domestic dissent through executive and legislative assaults on civil liberties. Ultimately, coercion is probably too expensive and unwieldy for a twenty-first century capitalist world order to function efficiently. Different cultures are responding to the globalization project through different ways of interpreting information and experience while foreign policy elites in Washington, employing a positivist epistemology, define the national interest, largely in the absence of public debate, in terms of America's assumed strategic needs. Particularly in times of crisis, these interests tend to be assessed vis-à-vis the perceived needs of the capitalist status quo (or, to use Gramsci's more precise concept, the contemporary hegemonic bloc). The implications of this way of conducting relations with the world is illustrated by a State Department memo, issued in the 1980s to justify support of Saddam Hussein as a counter-force to Islamic fundamentalism, which begins, "Human rights and chemical weapons aside, our interests run parallel to those of Iraq" (qtd. in Power, 2002). When this kind of thinking and policy is possible in a democratic republic, when human rights abuses and the use of chemical agents are trivialized when applied to nonAmericans, and when such thought processes affect the lives of billions of human beings worldwide, the outcome is predictable. It might be helpful to remind ourselves that, centuries ago, the barbarians, in the end, defeated Rome despite an advantage 
held by Rome's Emperors over America's Presidents: in Rome a slave was charged with the task of repeatedly whispering in the Emperor's ear,"you are mortal."

In the long run, a successful globalization project would involve the defense and re-structuring of core media, those constituting key nodal points in forging conceptual systems that are fundamental in the task of establishing rule through consent, through shaping how information and experience are interpreted and expressed. But Washington policy elites are entrenched in conceptualizations of time that are oppositional to the ways in which time is organized and conceptualized by many who oppose them. The biases underlying the globalization project-including the systemic drive to control space (to control organizational and conceptual aspects of production, distribution, exchange and consumption) - tend to involve an accompanying annihilation of time. But in this effort to establish a twenty-first-century hegemonic order, this neglect of time, as expressed in the promotion of erratic time, time in advance of itself, and deceptive time, constitutes the seeds of the project's ultimate collapse.

\section{Alice and America Through the Looking Glass}

From a political economy perspective, a response might involve two broadly defined initiatives. First, key technological, organizational and institutional media need to be identified and re-structured in ways that can help us pursue a more social and reflexive sense of time. Innis emphasized the strategic need to counter-balance the predominance of linear time (an ordered, chronological, progress-focused sense of time) with social time (a relatively organic, reflexive and historical appreciation of time) through the structuring of media. Again, to borrow from Gurvitch, three precise ways of organizing and conceptualizing time also can be emphasized: enduring time is an ecological sense of time, historically associated with peasant or hunter-gatherer social formations; cyclical time is a sense of continuous time in which change is understood through continuity, usually associated with mystical/archaic collectivities; and explosive time is a sense of the present and past dissolved into a transcendent future-a way of organizing and conceptualizing time in keeping with revolutionary or transformational movements (Gurvitch, 1964).

The second plank of an alternative strategy stemming from this analysis involves what Ian Parker calls the re-mythologizing of globalization. Rather than just de-mythologizing globalization-underlining its predominant simplifications, such as the decline of the nation-state, the sovereign authority of marketplace relations, and so forth-we might recognize that the future is not cast in stone (redressing, that is, time in advance of itself). Using the already dominant discourse of neo-liberalism and turning it on itself, rather than a globalization that is largely about the global driving the local (and the absolutes of the marketplace), a re-mythologized globalization could be about the local driving the global (Parker, 1994). A re-mythologized globalization, structured through media, might emphasize enduring, cyclical or explosive time.

While the systemic drive associated with capitalism generally promotes cultural homogenization and conceptual systems needed to survive in the marketplace, through commodification processes, the predominance of the price system, the universaliza- 
tion of the wage labour contract and so forth, a strategic effort could stress the politics of global diversity and the democratic choice to interact (or not interact!) with others. Some of the ideals being propagated by America's neo-imperialists to justify the globalization project-especially their purported idealization of democracy-can be used as the standards upon which mediated structures associated with the project might be judged as acceptable or unacceptable. Instead of a globalization project dominated by corporate needs and American-based ambitions, globalization might be re-mythologized to be more about the flowering of human and cultural rights through institutions, organizations and technologies, and the political-economic empowerment of local and national citizens (Harvey, 2000).

Today's neo-imperialist thinking in Washington, and the fragmented, temporally-limited and reactionary modes of resistance we are witnessing in response to the globalization project, leave me with little optimism that such concerted efforts to reclaim time will emerge voluntaristically. An immediate response might involve the use of Innisian political economy to trace the long-standing neglect of time expressed, for example, through those conceptual systems that have generated a Washington-based indifference to the historical-systemic conditions underlying the world's dependency on oil; the shortsighted support of American administrations for repressive regimes to secure this resource; and the American public's general inability to think about the long-term implications of its government's reactionary responses to reactionary barbarians.

The Lewis Carroll (un)realities quoted at the start of this essay are reminiscent of Leo Panitch's use of Through the Looking Glass as a metaphor for capitalism. In his book, Renewing Socialism (2001), Panitch reminds us of Alice's run through the Red Queen's garden. Despite her efforts to keep pace, Alice can do little more than stay in the same place. The Red Queen explains, "if you want to get somewhere else," you must "run at least twice as fast...!" For Panitch, the garden is analogous to the upside-down world of capitalism (Panitch, 2001: 139-40). The endless search for markets and profits compels an ongoing acceleration of life, involving breakneck change in relation to production, distribution, exchange and consumption. State policies are forged with little foresight regarding their inherent contradictions. Through such abstractions and (il)logic, a twenty-first century world order marches on with little time to reflect, reconsider, and reorganize in a sustained fashion. These are the historical conditions in which the current administration has forged its neo-imperialist agenda. And while these conditions do not in themselves directly determine the unilateralist, militaristic and reactionary events unfolding around us, they do, I think, constitute the politicaleconomic conditions in which neo-imperialist policies have been structured. As Henry Kissinger remarks in his most recent book, "the U.S. is enjoying a preeminence unrivaled by even the greatest empires in the past" (qtd. in Golub, 2002), but, nevertheless, the pillars upon which this empire is constructed entail profound contradictions and horrific implications.

What I hope the reader takes from this analysis is that the ascendancy of a reactionary U.S. foreign policy itself says something important about a more general historical trend: the mediated, spiraling neglect of time. The underlying strength of bias and medium theory is that they bring together, historically and holistically (or, more accurately, they mediate), agency and structure. Beyond a moment in history in which neo- 
conservative hawks have seized the reigns of power, historical and cumulative tendencies are discernable involving how what is known is known and how the politicaleconomic structures and dynamics underlying particular ways of thinking are generating potentially fatal policies in Washington.

\section{Notes}

\section{Thank you to Robert Babe, Larissa G.Webb and Tamara Trownsell.}

2. As Mel Watkins remarks, "Innis ... did something unlikely to make him popular with American public opinion.... He studied the United States itself and did so with a critical eye. He wrote about its press, its militarism and their interconnection.... Innis saw the contemporary media as having the common characteristic of obliterating time and of destroying the balance between time (duration) and space (territorial control) that was the hallmark of enduring empires" (2002).

3. The "Washington Consensus" generally refers to the common sense views of America's political-economic establishment including, and perhaps most important, the policy prescriptions of the U.S. Treasury Department and Federal Reserve.

4. The timing and political implications of Hardt and Negri's fashionable book, Empire (2000), surely has played some part in this development. The Gulf War, according to its authors, was pursued in the interest of an empire that has neither a core nor discernable boundaries. As such, Hardt and Negri (unintentionally, perhaps) legitimize America's use of coercive power. If one assumes that the post-Cold War military interventions of the United States are little more than structural expressions of a global network of interests reflecting liberal-democratic principles rather than exploitive ambitions (as Empire, the writings of Max Boot and others argue), few in the American foreign policy status quo would feel embarrassed by being associated with this kind of neo-imperialist project.

5. Elsewhere, Panitch has documented that the World Bank does not view itself (nor other international organizations for that matter) as substitutes for the nation-state. Rather, the mandate of such international arrangements is to push forward the restructuring of states in such a way that, according to the Bank, "a mechanism for countries to make external commitments [is instituted], making it more difficult to back-track on reforms" (qtd. in Panitch, 1998: 20).

6. I have often been impressed by the presence in Washington of professional organizations and lobbyists representing corporations conducting little or no business in the United States itself. Quite unlike other world capitals, such as London, Tokyo, or Berlin, the Executive branch, Congress and the many influential think-tanks and other organizations located in Washington constitute the political, economic and ideological core from which the globalization project is being promoted.

7. For an example of this perspective, see Michael Ignatieff (2002).

8. According to Weller, et al., not only have market fundamentalist policies failed to reduce poverty, "greater integration of deregulated trade and capital flows ... has likely undermined efforts to raise living standards for the world's poor" (Weller, et al., 200I: I). 
9. Just one example of this is the Free Trade Area of the Americas (FTAA) - the transcontinental successor to NAFTA - which now is on top of the foreign economic policy agendas of many executives in corporate America and many others based in the other thirty-four Western hemisphere countries involved in the talks. Included in the administration's National Security Strategy, the FTAA proposal goes beyond the usual free trade wish list of selectively eliminating tariffs, reducing barriers to foreign investment, banning national controls over the flow of capital, establishing a court mandated to enable corporations to sue governments over laws impeding potential profits, and so forth. Its proponents also want the FTAA to, among other things, end the ability of governments to shield essential public services such as healthcare, education and water from the profit-seeking interests of corporations.

10. For example, while both Chile and Singapore were involved in bi-lateral trade pact discussions with the United States prior to the American invasion of Iraq, the political fallout from one country's support and the other's opposition underlines the role of politics in economics and economics in politics. As a result of Chile opposing the war, the U.S.-Chilean deal was delayed - a slap on the wrist of the Chilean government and those it represents for not marching in lockstep with America at the UN. Singapore, on the hand, after officially backing "Operation Iraqi Freedom," and despite its geographic location well outside the hemisphere, has been rewarded with expedited negotiations (Blustein, 2003: EI). In comments regarding the distribution of re-construction contracts in post-War Iraq, Vice President Dick Cheney has admonished France and Germany. Corporations based in these countries should not expect to fully participate, said the vice president, adding that perhaps "time will help in terms of their [government's] outlook" (qtd. in Lapham, 2003: I I).

II. Mythologies also serve to de-politicize such developments. As Roland Barthes writes, through myth "history evaporates.... Nothing is produced, nothing chosen.... This miraculous evaporation of history is another form of concept common to most bourgeois myths: the irresponsibility of man" (qtd. in Babe, 1995: 182).

12. Over the course of my lifetime (I was born in 1962), the gap between the richest twenty percent of the world and the poorest twenty percent has doubled. From 1970 to 1998, the total external debt of developing countries rose from $\$ 90$ billion to $\$ 2$ trillion. Today, 2.8 billion of the world's six billion people live on less than $\$ 2$ a day (George, 2002: 21).

13. According to David Harvey, the rise of competitive and perhaps even reactionary forms of localism and nationalism should be anticipated in a world characterized by rapid change, free flowing capital and falling spatial-temporal barriers. In such political-economic conditions, concerted efforts to make "the local" comparatively attractive for investors, or portraying one's culture as relatively (and chauvinistically) ideal, becomes more likely. Indeed, in an increasingly interconnected world characterized by the normalization of rapid change and instability, one's identification with a place probably will remain an important psychological mooring. In the context of capitalist dynamics and the globalization project, in this clinging to place-bound identities, ironically, says Harvey, "oppositional movements become a part of the very fragmentation which mobile capitalism and flexible accumulation" feed upon

(Harvey, 1989: 303). 
14. In the United States, where there are more television sets than telephones, the T.V. also may facilitate the separation of people sharing the same residence. Moreover, the popularity of the Internet, gaming and personal computing likely is deepening this search for human connection and community paradoxically through the use of telecommunications and consumer electronics.

15. In making these assertions, one does not have to be engaged in essentialist judgements that, for instance, such cultural tendencies are inherently good or bad. In the context of gender relations in relatively traditional political economies, for example, through the institution of consumption, expressed through the targeted advertising of commodities and lifestyles to women, while not instigating the struggle to reform another institution-patriarchy-more than just some kind of automatic base-to-superstructure (or developed capitalist economy "meets" traditional culture) transformation may be taking place. Consumption is mediating gender identities and imaginations-shaping struggles through its influence on how people process information and their experiences into what is known to be reality. From this perspective, contemporary consumption, in this instance, can be seen as a medium through which the priorities of the collective are being challenged by political movements representing the "rights" of the ascendant (male and female) individual.

16. A member of the Pentagon's Defense Policy Board, Ken Adelman, hopes that the conquest of Baghdad "emboldens leaders [in the United Sates] to take drastic, not measured approaches" (qtd. in Lapham, I I).

17. Philip J. Carroll, the oil industry executive selected by the Department of Defense to coordinate Iraq's post-war Ministry of Oil, favors the country's withdrawal from OPEC. According to the Business Section of The Washington Post,

Flows of Iraqi oil to the world market unconstrained by OPEC quotas could further erode the cartel's already limited ability to set prices and might even trigger a price war, eating into profits of its member countries. Such an outcome would surely delight the Bush administration as well as buyers of gasoline in the United States, the world's largest oil consumer. With this in mind, commentators ... have contended that the real purpose of Bush's war in Iraq was to put in place a government that would break OPEC. Such an outcome would dismay the world's largest oil producer, Saudi Arabia.... (Goodman, 2003: EI-E2)

18. In the words of Michael Ledeen of the American Enterprise Institute, "Every ten years or so, the United States needs to pick up some crappy little country and throw it against the wall, just to show the world we mean business" (qtd. in Lapham, I I).

19. Just before declaring war on Iraq in March 2003, and in what was only the second press conference of his Administration, President Bush tried to explain his pending decision. More insightful than his reasons for overthrowing the Hussein regime was what the event revealed in regard to how the President was thinking. As columnist David Broder observed, what it made clear "was his [Bush's] extraordinary capacity to reject any efforts to put this matter in any broader context-his ability to simplify what otherwise would be a wrenching decision" (Broder, 2003: A23).

\section{References}

Arkin, William M. 2002. Military Bases Boost Capability but Fuel Anger. Los Angeles Times 6 January, AI. 
Babe, Robert. 1995. Communication and the Transformation of Economics. Boulder: Westview Press.

Blustein, Paul. 2003. Trade Accords Become a U.S. Foreign Policy Tool. The Washington Post, 29 April, EI.

Boot, Max. 200I. The Case for American Empire. The Weekly Standard 7 (5).

<http: //www.weeklystandard.com/Content/Public/Articles/000/000/000/3 I8qpvmc.asp>

Broder, David. 2003. Bush’s Minimalist Mantra. The Washington Post II March, A23

Brzezinski, Zbigniew. 1997. The Grand Chessboard: American Primacy and its Geostrategic Imperatives. New York: Basic Books.

Coen, Robert J. 2002. Presentation on Advertising Expenditures. http://www.universalmccann.com/Bob_Coen_Report_July_2002.doc.

Comor, Edward A. 1998. Communication, Commerce, and Power. New York: St. Martin's.

Comor, Edward. 2000. Household Consumption on the Internet. Journal of Economic Issues 34: $105-16$.

Ewen, Stuart. 1976. Captains of Consciousness. New York: McGraw-Hill.

Finnegan, William. 2003. The Economics of Empire. Harper's 306: 4I-54.

George, Susan. 2002. Where Have All the Protestors Gone? Guardian Weekly I-7 August, 2I-2.

Gibbs. 200I.Washington’s New Interventionism. Monthly Review 53 (4): I5-37.

Gitlin, Todd. 200I. Media Unlimited. New York: Metropolitan Books.

Golding, Peter and Graham Murdock. 199I. Culture, Communications, and Political Economy. In Mass Media and Society, edited by J. Curran and M. Gurevitch. London: Edward Arnold.

Golub, Philip S. 2002. The Dynamics of World Disorder. Le Monde Diplomatique English internet edition, September. <http: //www.arena.org.nz/westemp.htm>

Goodman, Peter S. 2003. U.S. Advisor Says Iraq May Break with OPEC. The Washington Post I7 May, EI-E2.

Gurvitch, Georges. 1964. The Spectrum of Social Time. Dordrecht: D. Reidel.

Haas, Richard. 2000. Imperial America. Paper presented at the Atlanta Conference. Puerto Rico. <http: //www.brook.edu/views/articles/haass/2000imperial.htm>

Hardt, Michael and Antonio Negri. 2000. Empire. Cambridge, MA: Harvard University Press. Harvey, David, 1989. The Condition of Postmodernity. Oxford: Basil Blackwell. 2000. Spaces of Hope. Berkeley: University of California Press.

Ignatieff, Michael. 2002. Nation-Building Lite. New York Times Magazine. 28 July. <http: //www.globalpolicy.org/security/issues/afghan/2002/0728buildinglite.htm> Innis, Harold A. [195I] 1982. The Bias of Communication. Toronto: University of Toronto Press. 
. [1950] 1986. Empire and Communications.Victoria: Press Porcepic.

Kiesling, John Brady. 2003. Letter of resignation to Secretary of State Colin L. Powell. New York Times 27 February <http: //truthout.org/docs_03/030103A.shtml>

LaFeber, Walter. 1963. The New Empire. Ithaca, NY: Cornell University Press.

Lapham, Lewis. 2003. The Demonstration Effect. Harper's 306: 7-9.

Leiss, William, S. Klein, S. Jhally. 1990. Social Communication in Advertising. Scarborough: Nelson Canada.

Levinson, Paul. 1988. Mind At Large. Greenwich, CT: JAI Press.

Marx, Karl and Frederick Engels. [1846] 1970. The German Ideology. New York: International.

The National Security Strategy of the United States of America. 2002. Washington: The White House. <http: //www.whitehouse.gov/nsc/nssall.html>

Panitch, Leo. 1998. “The State in a Changing World”: Social-Democratizing Global Capitalism? Monthly Review 50: II-22.

—. 200I. Renewing Socialism. Boulder: Westview Press.

— Variety in the Making of Global Capitalism. Unpublished paper presented at the Wake Forest Conference on the Convergence of Capitalist Economies.

Parker, lan. 1994. Myth, Telecommunication and the Emerging Global Informational Order. In The Global Political Economy of Communication, edited by E. A. Comor. New York: St. Martin's Press.

Perle, Richard, J. Colbert, C. Fairbanks, Jr., D. Feith, R. Loewenberg, D. Wurmser, and M.Wurmser. 1996. A Clean Break: A New Strategy for Securing the Realm. Washington, DC: Institute for Advanced Strategic and Political Studies. < http: //www.israeleconomy.org/stratl.htm>

Power, Samantha. 2002. Interview on Now with Bill Moyers. PBS television, 8 November.

Project for the New American Century. 1997. Statement of Principles. <http: //www.newamericancentury.org/statementofprinciples.htm>

Rosen, Steven Peter. 2002. The Future of War and the American Military. Harvard Review 104 (5): 29.

Soros, George. 2002. George Soros On Globalization. New York: Public Affairs.

Stiglitz, Joseph E. 2002. Globalization and lts Discontents. New York:W. W. Norton.

UNDP. 1999. Human Development Report 1999. New York: Oxford University Press.

Watkins, Mel. 2002. Heralding Innis. THIS Magazine. <http://www.thismagazine.ca/36_2/col_I.html.>

Weller, Christian E., R. E. Scott, A. S. Hersh. 200I. The Unremarkable Record of Liberalized Trade. Economic Policy Institute Briefing Paper. Unpublished. Washington, DC. <http:

//www.epinet.org/content.cfm/briefingpapers_sept0 Iinequality>

Williams, William A. [1959] 1972. The Tragedy of American Diplomacy. New York: Delta. 